\title{
THE SOUTH AFRICAN NAVY AND ITS PREDECESSORS, 1910-2010: \\ A CENTURY OF INTERACTION WITH COMMONWEALTH NAVIES
}

\author{
Professor André Wessels ${ }^{1}$ \\ Department of History, University of the Free State
}

\begin{abstract}
In this article, the history of the South African Navy (SAN) and its predecessors is reviewed, as well as the interaction with other Commonwealth navies during the years 1910 to 2010. Although the Union Defence Forces were established in 1912, the Union only acquired its first naval force in 1922, when the South African Naval Service (SANS) was formed. In the meantime, the country's naval defence was conducted by the Royal Navy (RN). During World War I, 164 members of the South African Division of the Royal Naval Volunteer Reserve served in the RN. The SANS's three small ships were withdrawn from service in 1933 to 1934, and when World War II broke out, the country's naval forces had to be built up from scratch - but soon played an important role in patrolling the Cape sea route (and also saw action in the Mediterranean). After the war, South Africa's naval forces were rationalised, but - in the context of the Cold War and the Soviet threat to the Cape sea route - the SAN then gradually grew in size and importance, albeit that it was (and today still is) small in comparison to major Commonwealth navies. In 1957, the SAN acquired the RN's Simon's Town Naval Base. Many exercises were held with the RN and other navies, but gradually South Africa became more isolated internationally because of the National Party government's racially-based policy of apartheid. In due course, this impacted negatively on the
\end{abstract}

${ }^{1}$ André Wessels is a senior professor in the Department of History at the University of the Free State. He is also a visiting fellow in the School of Humanities and Social Sciences, University College, University of New South Wales at the Australian Defence Force Academy (UNSW@ADFA), Canberra. This article is based on a paper that was delivered at the 2009 King-Hall Naval History Conference in Canberra. The sources used in writing the article are freely available. 


\section{0}

SAN and its interaction with other navies. In 1975, the Simon's Town Agreement was abrogated and in 1977, the United Nations imposed a mandatory arms embargo against South Africa. In the meantime, the Republic of South Africa (RSA) became embroiled in the Namibian War of Independence (1966-1989) - a war that spilled over into Angola. The SAN played a small, albeit important, role in the war, but the conflict affected the navy negatively. The advent of the truly democratic RSA in 1994 opened new opportunities for the SAN, and since then, the SAN has undertaken many flag-showing cruises to several Commonwealth and other countries, while many foreign warships, including from Commonwealth navies, have visited the RSA and exercised with the SAN.

\section{Introduction}

31 May 2010 was the centenary of South Africa as a unitary state - a hundred years since the Cape Colony, Natal, the Transvaal and the Orange Free State amalgamated on 31 May 1910 to form the Union of South Africa. The fact that most black, brown and Indian inhabitants did not receive full political or civil rights in due course led to many problems, as well as a liberation struggle (1950s-1994), which impacted negatively on the country's foreign relations, including (especially from the 1960s to 1994) naval contact with Commonwealth countries. Proceeding from the assumption that the South African Navy (SAN) and its predecessors played a vital role in safeguarding the strategic Cape sea route in the interest of the Commonwealth, as well as of the Western World, the aim of this article is to provide a brief review of the chequered history of the SAN and its predecessors, with the emphasis on interaction with Commonwealth navies (31 May 1910 - 31 May 2010). Questions that will be addressed include the following: To what extent was contact with Commonwealth navies limited to the Royal Navy (RN), and why? What were the implications of the so-called war years (1966-1989) for the SAN? How have the political changes brought about by the advent of the so-called new South Africa in 1994 affected the SAN, and in particular its relations with other Commonwealth countries? Where possible, parallels will be drawn between developments in the SAN and developments that took place in the navies of other Commonwealth countries.

\section{The establishment of naval forces for South Africa, and their role until 1945}

For more than a century, the RN defended the Cape sea route and adjacent areas from its naval base in Simon's Town, and this continued to be the case even after Unification in 1910, when the RN retained this strategic base. However, there was a South African Division of the Royal Naval Volunteer Reserve (RNVR(SA)), 


\section{1}

which came into being on 1 July $1913 .{ }^{1}$ This followed after the establishment of the Union Defence Forces (UDF) on 1 July $1912,{ }^{2}$ but for the time being there was no navy. However, there was some naval interaction between South Africa and other British or former British territories. In 1913, for example, two new Australian warships, the battlecruiser HMAS Australia and the light cruiser HMAS Sydney, sailed from where they had been built in Britain via South Africa to Australia, visiting Cape Town and Simon's Town (26-29 August 1913), and the Australia also visited Durban (31 August -6 September). ${ }^{3}$

During World War I (1914-1918), members of the RNVR(SA) served in the South West African campaign. They also manned ships that patrolled South Africa's coasts against German surface raiders and helped to clear up the mines laid by the surface raider Wolf. A total of 164 members of the RNVR(SA) served in the $\mathrm{RN}$ in the course of the conflict, and in that sense cooperated with other members of the British Empire. ${ }^{4}$

On 1 April 1922, South Africa's first-ever naval force came into being with the establishment of the South African Naval Service (SANS), which had at its disposal a small hydrographic survey ship, HMSAS Protea (an ex-RN minesweeper), and two minesweeping trawlers (also ex-RN ships). However, the Great Depression (1929-1933) and other factors led to the virtual demise of the SANS - the Protea was withdrawn from service in 1933, and both trawlers were withdrawn during the next year. ${ }^{5}$ Compare this state of affairs with the situation that prevailed in, for example, Australia - a country which, in 1922 already, had a relatively large navy (established on 1 March 1901 as the Commonwealth Naval Forces), with three light cruisers, twelve destroyers, three sloops, one submarine, one torpedo boat, three depot ships and two other auxiliaries. ${ }^{6}$ In the case of New Zealand, the New Zealand Division of the Royal Navy was established in 1921, and had two light cruisers in $1922 .^{7}$ In the meantime, the British Commonwealth developed from the Imperial Conferences, with Britain and its dominions acquiring equal status in the British Commonwealth of Nations in 1926 - a relationship that was formalised by the Statute of Westminster (1931).

By the time World War II broke out on 1 September 1939, the SANS amounted to little more than a nominal naval organisation, with only two officers and three ratings ${ }^{8}$ and, obviously, no warships. In comparison, when the war broke out, the personnel of the Royal Australian Navy numbered 5 440, with six cruisers, five destroyers, three sloops, one depot ship and one other auxiliary, ${ }^{9}$ while the New Zealand Division of the Royal Navy had approximately 1340 personnel (of whom some $46 \%$ were $\mathrm{RN}$ ), two cruisers and a minesweeper. ${ }^{10}$ 


\section{2}

Almost from the start of hostilities, German surface raiders, submarines and mines threatened the Cape sea route, as did Italian and Japanese submarines in due course, and a total of 133 merchant ships were sunk off the coast of South Africa, while only three enemy submarines were sunk in that area. ${ }^{11}$ The SANS was soon built up again, acquiring several minesweepers and small anti-submarine vessels (all of which were either converted trawlers or whale catchers). As from 15 January 1940, the SANS became known as the Seaward Defence Force (SDF), and took over the minesweeping activities off the South African coast. In due course it was also responsible for anti-submarine operations in South African coastal waters. From January 1941 onwards, a number of SDF anti-submarine trawlers served in the Mediterranean. On 1 August 1942, the SDF and the RNVR(SA) amalgamated to form the South African Naval Forces (SANF), which continued to safeguard the strategic Cape sea route as best they could. ${ }^{12}$ In October 1943, the South African Women's Auxiliary Naval Service (SWANS) was established. ${ }^{13}$ Political considerations of the day precluded black, brown and Indian South Africans from fighting in uniform, but many did serve, mostly as non-combatants, on board the SANF's "little ships", for example as cooks and general deck hands. ${ }^{14}$

After the conclusion of the war in the European theatre of operations, the SANF sent two of its ships to the Far East to serve in the continuing war against Japan. ${ }^{15}$ At least 2937 South Africans served in the RN during the war, of whom 191 died in active service. These South Africans served on board RN ships in all theatres of operations, and they also cooperated with other Commonwealth naval personnel - including in the struggle against Japan. ${ }^{16}$ South African ships and/or sailors served in all naval operational areas, and played a small but meaningful role in the defeat of the Axis powers, cooperating closely with the RN and the navies of the other Commonwealth countries. Once again, Simon's Town was also of great importance, and many Allied, mostly Commonwealth, warships visited its docks.

\section{The prosperous years, 1945-1966}

After the end of World War II, the SANF - in line with most other navies - was scaled down drastically. On 1 May 1946, the SANF was reconstituted as a permanent part of the UDF, with an authorised establishment of 60 officers and 806 ratings, but by that stage it only had three British-built "Loch"-class frigates, one small minelayer, two boom defence vessels, and eleven very small harbour defence launches. ${ }^{17}$ Its base, as from 1948, was the one that had been built for the RN on Salisbury Island in Durban during the war. ${ }^{18}$

In May 1948, the National Party (NP) came to power, ${ }^{19}$ and soon started with the implementation of its racially-based policy of separate development 


\section{3}

(apartheid), which in due course not only harmed millions of black, brown and Indian South Africans, but also the country's foreign relations, including those with Commonwealth countries. This in turn affected naval relations. However, for the time being, South Africa still had strong ties with the Commonwealth and with Western powers in general, because in the course of the 1950s and 1960s, the Cold War became more intense, and the West needed the support of South Africa in order to safeguard the strategic Cape sea route.

In the years 1945 to 1966 , the SANF (and later the SAN) sent its ships on many flag-showing cruises, the most noteworthy being the visit to Australia in 1951. The "Loch"-class frigate HMSAS Transvaal departed from her base in Durban on 26 December 1950 and arrived at Fremantle on 10 January 1951. From there, the ship sailed to Sydney to take part in the two-week Australian Jubilee Celebrations. On arrival in Sydney on 29 January, the Transvaal took part in exercises with ships of the Australian, New Zealand, Indian and Pakistani navies, as well as the RN. The South African ship subsequently visited Jervis Bay, Melbourne, Adelaide and, once again, Fremantle, before returning to South Africa, arriving back in Durban on 4 March 1951. This was the longest and most ambitious exercise that had been undertaken by the SANF since its inception, and the epic voyage was a resounding success - underlining the important role that navies can play in diplomatic relations. ${ }^{20}$ While this grey diplomat was away, the SANF was renamed as the South African Navy on 1 January 1951, and on 20 June 1952, the prefix of all South African naval ships was changed from HMSAS to SAS, reflecting the growing Afrikaner nationalism since the NP had come to power. ${ }^{21}$

In 1954, the South African and British governments started negotiations on the future of the RN's base at Simon's Town. The Simon's Town Agreement was concluded in 1955. In accordance therewith, South Africa undertook to expand its navy by purchasing an additional six frigates (in practice, only four frigates were acquired), ten coastal minesweepers and four patrol boats from Britain, and the Simon's Town Naval Base was formally transferred to South Africa on 2 April 1957. However, according to the Agreement, Britain, the other Commonwealth countries and allies could still use the base facilities. ${ }^{22}$ Although the Commonwealth Office had reservations about handing over the Simon's Town Base to South Africa, and although the NP government had a political rather than a strategic naval agenda with regard to its endeavours to acquire the base, this step did, in fact, eventually lead to the expansion and development of the SAN. ${ }^{23}$

After World War II, ships of the SANF (and later the SAN) regularly exercised with ships of the RN, and also sometimes with visiting warships from France, Portugal and the United State of America (USA). Thus, interaction with the 


\section{4}

Commonwealth was still limited to cooperation with the RN, but this cooperation was of considerable importance. After 1957, an RN frigate was continuously based in Simon's Town until 1966, many other RN warships continued to visit Simon's Town as well as other South African ports, and there were also sporadic visits by grey diplomats from other countries, including Commonwealth countries. ${ }^{24}$

From 1955 to 1959 , the SAN commissioned a frigate, ten coastal minesweepers and four patrol boats that it had bought from Britain. ${ }^{25}$ In the meantime (until 1959), the Australian Navy acquired two aircraft carriers (1948 and 1955), implemented its "long haul" defence policy and "forward defence", and also acquired five destroyers. After gaining independence in 1947, India acquired two cruisers, five frigates and, in due course, also an aircraft carrier. Pakistan acquired a cruiser and nine destroyers, New Zealand obtained two cruisers and six frigates, and Canada acquired an aircraft carrier, three destroyers and seventeen frigates that had been locally designed and built. ${ }^{26}$

The year 1960 was a turbulent one in the history of South Africa. The most important events included British Prime Minister Harold Macmillan's "Wind of Change" speech, the riots in Sharpeville and other so-called townships (which led to protests in many countries against South Africa), the banning of the African National Congress (ANC) and Pan-Africanist Congress (PAC), and the referendum during which the white electorate - by a small majority - voted in favour of their country becoming a republic. ${ }^{27}$ In March 1961, the South African Prime Minister, Dr H.F. Verwoerd, went to Britain to attend the annual Commonwealth conference, with the intention of requesting permission for his country to remain in the Commonwealth after becoming a republic (as was the case with India), but when certain Commonwealth representatives sharply criticised the South African government's apartheid policy, Verwoerd withdrew South Africa's application for continued membership on 15 March 1961. And so, on 31 May 1961, South Africa became a republic outside of the British Commonwealth. ${ }^{28}$ However - at least for the time being - this did not impact negatively on the naval relations of the Republic of South Africa (RSA) with the RN or other countries. Flag-showing visits by SAN warships continued, and South Africa continued to welcome many foreign grey diplomats to its ports. ${ }^{29}$

Meanwhile, many African countries had become independent, changing the face and character of the continent and to some extent also that of the Commonwealth, and their attitude towards South Africa hardened. Internationally, South Africa was gradually becoming a pariah state. In 1963, the Security Council of the United Nations (UN) approved a voluntary arms embargo against the RSA, and when the Labour Party came to power in the United Kingdom (UK) in 1964, 


\section{5}

South Africa's oldest naval ally decided that it would henceforth supply no further arms to the country. Nevertheless, for many years, the RN continued to provide training on RN courses to SAN officers and ratings. ${ }^{30}$ By this time, storm clouds were also brewing in South West Africa (SWA, today Namibia).

\section{The "war years", 1966-1989}

In 1960, the black inhabitants of SWA found an important mouthpiece when the South West African People's Organisation (SWAPO) was established. In due course, SWAPO resorted to the taking up of arms against what they regarded as the unlawful South African occupation force in SWA, and on 26 August 1966, the first clash between SWAPO cadres and South African security forces took place. ${ }^{31}$ Over the course of time, a full-scale guerrilla conflict ensued in the north of SWA, which spilled over into Angola (from whence SWAPO launched most of its attacks), became intertwined with the liberation struggle (and later the civil war) in Angola, and culminated in a conventional conflict in Angola, in which thousands of Cuban soldiers - as well as advisors from many other countries - were also involved.

The South African Defence Force (SADF) mainly deployed the South African Army "up north", supported by aircraft and helicopters of the South African Air Force (SAAF), and with members of the South African Medical Service playing an important role in evacuating and treating casualties. The role of the SAN in the conflict was ostensibly very small, and yet - as will be pointed out in due course - it was in reality quite significant. ${ }^{32}$ However, of greater importance in terms of the history of the SAN is the fact that during (and because of) these war years, the composition and role of the SAN gradually changed, as did South Africa's international position, which had far-reaching consequences for naval cooperation between the RSA and Commonwealth (and other) countries.

International pressure was mounting against the RSA, but for the time being, the SAN still enjoyed normal interaction with the navies of most Western countries. When the Six-Day Arab-Israeli War (1967) led to the closure of the Suez Canal (1967-1975), it also led to an increase of commercial traffic around the Cape, while many more foreign warships now also used the Cape sea route, often calling at one or more South African ports. For example, in 1968 at least 44 RN (and auxiliary) ships visited Simon's Town, in 1969 there were at least 39 such visits, in 1970 at least 36 visits, and in 1971 at least 50 visits. $^{33}$

In 1967, the SAN acquired an oil tanker, converted her into a replenishment ship, and commissioned her as SAS Tafelberg - the first such ship in the Navy. ${ }^{34}$ Henceforth, the SAN could deploy its other ships independently of foreign ports and over larger distances than ever before. This capability was 


\section{6}

successfully demonstrated when the tanker accompanied the frigates SAS President Kruger and SAS President Steyn when they visited Argentinean ports for the first time in October to November 1967..$^{35}$

Over and above the visits by RN ships already referred to, 1968 also brought two other significant Commonwealth visitors to South African shores. The Pakistani submarine Ghazi was in Simon's Town from 28 March to the beginning of April 1968, en route back from Turkey (where she had been refitted) to Pakistan. ${ }^{36}$ In the meantime, the Royal Australian Navy decided to acquire six British-built "Oberon"-class submarines. The second of these, HMAS Otway, visited South African ports on her delivery cruise, arriving in Cape Town at the end of July 1968 and in Simon's Town on 27 August, and also visiting Port Elizabeth and Durban before crossing the southern Indian Ocean to Australia. ${ }^{37}$

The above-mentioned courtesy visit by an Australian naval unit to South African ports was followed by the SAN's second (and, thus far, last) flag-showing cruise to Australian shores. A task force comprised of the frigates SAS President Steyn and SAS President Pretorius, and the replenishment ship SAS Tafelberg, left Simon's Town on 7 October 1968 for the long trip across the Indian Ocean to Fremantle (arriving on 23 October, departing on 26 October), Sydney (2-8 November), Melbourne (10-14 November), and back to Fremantle (18-21 November). The task force arrived back in Simon's Town on 3 December 1968, having sailed 14642 nautical miles in the course of their 58-day cruise. ${ }^{38}$

In line with many other navies, the SAN decided during the course of the 1960s to acquire submarines in order to enhance the strength of the Navy. Several Commonwealth navies had already followed the same path, with Canada acquiring its first modern submarine in 1961 (having had two submarines from 1914-1920), Pakistan in 1964, Australia (to which reference has already been made) in 1967 (having had a few submarines in World War I, and in the 1920s to the beginning of the 1930s, and one for a short time during World War II) and India in $1968 .{ }^{39}$ The SAN would have preferred to acquire British "Oberon"-class submarines, in line with Canada and Australia, but when the Labour Party came to power in the UK in 1964, it decided not to supply any further arms to South Africa, although it did not (at least for the time being) curtail naval or other military contact. Consequently, the RSA bought three "Daphné"-class patrol submarines from France (commissioned in 1970 to 1971$).^{40}$

The last major naval exercises involving the SAN and the RN took place in 1973 to 1974. This was also the last occasion, for 20 years, on which RN ships would visit the RSA, because on 16 June 1975 the Simon's Town Agreement was 


\section{7}

abrogated. ${ }^{41}$ While all these developments were taking place, the war "up north on the border" gradually intensified. Since 1966, the South African Police had been able to contain SWAPO's incursions, but in the light of the escalation of the conflict, the SADF took over the counterinsurgency operations in 1973. As long as there were pro-RSA governments in Angola and Mozambique (both still governed by Portugal) and in Rhodesia (governed by Mr Ian Smith), the RSA had a physical buffer separating it from the rest of Africa, and SWAPO, the ANC and the PAC found it difficult to infiltrate and attack targets in SWA and the RSA. But in 1974, there was a regime change in Portugal and during the next year, Portugal withdrew from Mozambique (which became independent on 25 June 1975) and Angola (11 November 1975). South Africa now had pro-communist neighbours, and the SAN's ships were no longer welcome in Mozambican and Angolan ports.

In October 1975, South African ground forces, supported by the SAAF, and with the tacit support of the USA, invaded Angola in support of the Frente Nacional para a Libertação de Angola (FNLA) and União Nacional para a Independência Total de Angola (UNITA). However, when the South African forces were already in sight of Luanda, political considerations forced them to withdraw, with the last troops leaving on 27 March $1976 .{ }^{42}$ Most of the fighting was carried out by the South African land and air forces, but the SAN played a small but noteworthy and successful role: For the duration of Operation Savannah, several SAN units were deployed off the coasts of SWA and Angola, either as single units or as task forces, including two submarines, two frigates, several minesweepers, and the Tafelberg. ${ }^{43}$

Strictly militarily speaking, the SADF was successful in Angola, but politically and diplomatically the RSA was nose-diving. The SAN received a somewhat late and reluctant invitation from the USA to send a warship to take part in its bicentennial independence celebrations in 1976. While the SAN frigate President Kruger was still on passage to the USA, riots broke out in the sprawling Soweto (black) township near Johannesburg, spreading to many other areas, and leading to the implementation of intensified measures by the apartheid regime to quell all opposition. This, together with the death in police custody of black consciousness leader Steve Biko (12 September 1977), in turn led to the further isolation of South Africa, including the imposition of an all-embracing mandatory UN arms embargo (4 November 1977). This dealt the SAN a serious blow, because the delivery of its two new Type-69A light frigates and two "Agosta"-class submarines, all nearing completion in France, was embargoed. ${ }^{44}$

By the mid-1970s, many so-called coloured people were already serving in uniform in the SAN, and when a training base for Indians was established on 15 


\section{8}

January 1975 , members from that community also joined the SAN in numbers, but black people were still barred from serving in uniform. In due course, more women would also serve in uniform in the Navy. While the SAN gradually rid itself of apartheid's shades, the RSA as a whole was still firmly under the control of the NP and its outdated policies. As the regime anticipated growing international isolation, also from the UK and other Commonwealth countries, it strove to acquire new allies. Links with Israel were established, and in 1977 to 1978 three "Reshef"-class missile-carrying fast-attack (strike) craft, built in Haifa, were commissioned by the SAN, followed by six similar craft built under licence in Durban. ${ }^{45}$ The SAN thus entered the missile age.

After 1977, the RSA was almost totally isolated internationally, with condemnation of its apartheid policy, as well as of its so-called unlawful occupation of SWA and destabilisation actions in Southern Africa, emanating from various podiums, including the UN and the Commonwealth. On 1 August 1980, the frigate SAS President Steyn was withdrawn from service, and when the frigate SAS President Kruger was recommissioned on 15 August 1980, the chief of the SAN made it clear that the frigate era of the SAN was virtually something of the past. The SAN had to adopt a new role: Henceforth it would no longer defend the Cape sea route in the interest of the West, but would concentrate on safeguarding the RSA's harbours and coasts, in due course becoming a small-ship force (with the strike craft being its backbone). The Army-dominated Defence Headquarters used the war "up north" as an excuse to drastically reduce the naval portion of the Defence budget (for example, from about $17 \%$ to less than $9 \%$ in 1979). ${ }^{46}$

"Up north", the SADF launched an extensive cross-border raid into Angola in August 1981, in which SWAPO suffered huge losses. After this operation, the SADF did not withdraw all its troops from Angola - small units remained to disrupt SWAPO's infrastructure. ${ }^{47}$ In the meantime, larger surface units of the SAN continued to undertake electronic and other patrols along both the west and east coasts of Southern Africa, sometimes in support of missions undertaken by special forces, strike craft and/or submarines. The lack of unclassified archival sources makes it impossible to give full credit to the SAN for its military achievements in this regard. The role played by the SAN in this context must still (if possible) be thoroughly researched.

On 18 February 1982, the SAN suffered its greatest (and most embarrassing) tragedy to date, when the frigate President Kruger sank after colliding with the replenishment ship Tafelberg. Sixteen lives were lost. ${ }^{48}$ (A similar incident had occurred 18 years earlier, entailing the loss of the Australian destroyer HMAS Voyager, with 82 lives, after it had collided with the aircraft carrier HMAS 


\section{9}

Melbourne on 10 February 1964.) ${ }^{49}$ In 1985, 15 SAN ships (of which all but one were of British origin) were withdrawn from service in an effort to save money. ${ }^{50}$ The only major acquisition during these years was the combat support ship SAS Drakensberg (11 November 1987), the largest ship thus far designed and built in South Africa. For two decades, she was the most important ship in the SAN. ${ }^{51}$ From 1985 to 1998 , the SAN would be a 24-hull navy. In the meantime, the war "up north" intensified, and UNITA would not have survived without SADF assistance. But in August 1988, the last SADF forces left Angola. Negotiations followed, which eventually also led to the withdrawal of the RSA from SWA (20 June 1989), and the latter territory at long last became independent, as Namibia, on 21 March $1990 .{ }^{52}$

During the 23 years of conflict, the SAN controlled the seas around Southern Africa, deterred superpowers from intervening from the sea, and enabled the South African Army to project its power in areas such as the north of SWA and in Angola. The SAN had played a small but very important role in bringing about a negotiated settlement in SWA and Angola (albeit that in the latter country, civil war flared up again and would drag on until 2002), but the SAN had to pay a high price: The costly RSA war effort meant less money for the Navy, which necessitated a scaling down of personnel and ships, and a change in naval policy. The 1989, the SAN was indeed a totally different navy from that of 1966, having lost all its major surface combatants, and with them its anti-submarine warfare capability, and retaining only a limited anti-aircraft capacity.

While the SAN shrank in the years 1966 to 1989, this was also true of the RN and the Royal Canadian Navy, known as of 1968 as the Canadian Forces Maritime Command. On the other hand, the New Zealand Navy's strength remained much the same, the Australian Navy's strength increased (owing to the acquisition of submarines), the navy of Pakistan was strengthened, while the Indian Navy's strength increased dramatically. ${ }^{53}$

\section{From the old to the new South Africa, and beyond, 1990-2010}

The end of the 1980s/beginning of the 1990s heralded the end of the Cold War, and 1990 marked the start of a new era in the history of the RSA, with the unbanning of several political organisations, followed in due course by the commencement of political negotiations and the first truly democratic election of 1994, which brought a predominantly black political organisation (the ANC) to power. The SADF was transformed into a new South African National Defence Force (SANDF), and on 17 July 1994 - after an absence of 33 years - South Africa once again became a member of the Commonwealth. ${ }^{54}$ 


\section{0}

With political changes in the air, and in anticipation of great opportunities lying ahead for the SAN, the Navy embarked on several flag-showing cruises. ${ }^{55}$ Thus, even before political parties in the RSA had sat down for negotiations, and before the country had been officially welcomed back by the international community, the SAN was already restoring military and diplomatic ties and, in some cases, forging new ones. Of course, it must be kept in mind that the SAN emerged from the apartheid era with the least tarnished reputation of all the armed forces.

Visits to African Commonwealth countries followed. In June 1992, for example, two strike crafts visited Kenya, ${ }^{56}$ after which that country was also visited by the Tafelberg in September 1992, ${ }^{57}$ shortly before the ship was withdrawn from service, and replaced by a former Ukrainian-built Arctic icebreaker supply ship, commissioned as SAS Outeniqua (8 June 1993) ${ }^{58}$ Over and above the fact that the SAN assisted African Commonwealth countries in patrolling their coasts (in particular with regard to illegal fishing), the SAN also carried out survey work along the coasts of some of these countries. ${ }^{59}$ In May 1993, the Drakensberg visited the UK for the $50^{\text {th }}$ anniversary of the Battle of the Atlantic, ${ }^{60}$ and in January 1994, the RN paid its first visit to South Africa in nearly 20 years. ${ }^{61}$

Shortly after the watershed elections of April 1994 and the inauguration of Mr Nelson Mandela as the RSA's first democratically elected president, the Drakensberg departed on a 92-day cruise to show the new flag of the new RSA in overseas ports, including Rosyth in Scotland (in order to also take part in the Joint Maritime Course 942 exercise with other navies), London (to coincide with South Africa's re-admittance to the Commonwealth on 17 July 1994) and Portsmouth. ${ }^{62}$ Visits by several SAN ships to other Commonwealth countries followed. ${ }^{63}$ The years following the RSA's re-admittance to the Commonwealth and to the international community at large were therefore characterised by an enormous increase in the SAN's diplomatic and humanitarian opportunities and responsibilities. In the light of the fact that the Navy no longer had any destroyers or frigates, combat support ships and small combatants were deployed as grey diplomats.

In 1994 to 1997, a stream of foreign grey diplomats also visited South African ports, including RN ships and ships from other Commonwealth countries, namely India, Malaysia, Pakistan, Mauritius, Kenya and Singapore. ${ }^{64}$ The SAN continued to pay visits to African (and sometimes other) Commonwealth countries to strengthen ties and assist where necessary and possible, and foreign grey diplomats continued to stream to the RSA. This was in particular to be seen in April 1997 when the SAN's $75^{\text {th }}$ anniversary was commemorated, which included South Africa's first-ever international fleet review. ${ }^{65}$ The SAN received an invitation to send a ship to attend Australia's centennial in October 2001. The combat support 


\section{1}

ship Outeniqua was on her way to Australia when the fleet review that would have taken place in Sydney was cancelled in the wake of the 11 September terror attacks in the USA, and the ship was consequently diverted to La Réunion. ${ }^{66}$

In the meantime, in April 2001, the navies of South Africa and Australia cooperated, for the first time ever, in apprehending a fishing trawler that was fishing illegally in Australia's Exclusive Economic Zone. Operation Lariat was a great success, providing ample proof of how well Commonwealth naval personnel can cooperate with one another. ${ }^{67}$ In August 2003, the South African and Australian navies once again cooperated in apprehending a suspect fishing boat in what became known as Operation Lariat II. ${ }^{68}$

Soon afterwards, the first of the SAN's four new German-built frigates arrived in Simon's Town on 4 November 2003, followed by the others in the course of 2004. They were followed by three new German-built submarines (2006-2008), which replaced those of the "Daphné" class. ${ }^{69}$ These new ships and submarines formed part of the arms package that was approved by the South African cabinet and subsequently announced on 18 November 1998 - comprising a timely "emergency buoy" thrown out at the SANDF, and the Navy in particular. ${ }^{70}$

For the first time since 1985, the SAN now has major surface combatants that can be used for extensive patrol work, but also to take part in exercises with ships from other countries. See in this regard, for example, the Exercise Good Hope IV held with units of the German navy (February-March 2010). ${ }^{71}$ In addition, these new surface combatants can be deployed as impressive grey diplomats on tailormade flag-showing cruises, and since 2006, the new SAN frigates have indeed visited several Commonwealth and other countries. ${ }^{72}$ In the meantime, foreign grey diplomats continue to visit South Africa's shores, in particular ships from the UK, but during the years 2005 to 2010, there have also been visitors from other Commonwealth countries, such as Australia (July 2005), Pakistan (July 2006) and India (June 2005, September 2006 and May 2008). ${ }^{73}$ With the exception of New Zealand, Nigeria and Ghana, South Africa has, in the course of the past century, hosted warships from most of the major Commonwealth countries in peacetime, while SAN warships have visited all major Commonwealth countries, with the exception of New Zealand.

\section{Concluding perspectives}

The Commonwealth was and is an important organisation that through the years has played a significant role on the international stage. Close ties have also been forged between many of the Commonwealth member states, including with regard to naval cooperation. After the United States Navy, the "Commonwealth 


\section{2}

Navy" was and still is the world's most powerful naval force. For several decades, the latter navy has played a major role in sea-lane security and the protection of trade routes. In this regard, the SAN and its predecessors have played a significant role both in times of war and relative peace. As has been indicated in this article, the RN was for many decades the SAN's main naval partner, until the Simon's Town Agreement was abrogated in 1975 and the RSA became more isolated than ever before. The country had to seek new allies, and the SAN established close relations with Israel, the Republic of China (Taiwan) and Chile. In the course of the $20^{\text {th }}$ century and beyond, contact with Commonwealth navies has to a large extent been limited to contact with the RN - initially because of the physical RN presence in South Africa, owing to the fact that the RN controlled the Simon's Town Naval Base until 1957, but also because of political considerations (with many countries boycotting South Africa because of the racial policy that was followed until 1990, with even Britain eventually severing military ties). Other contributing factors in this regard included the distance of South Africa from far-flung countries such as, for example, Canada, Australia and New Zealand (with other countries also having other commitments and spheres of influence), as well as the relatively small size of the SAN. Since 1994, most of the naval ties between South Africa and other Commonwealth countries have chiefly entailed contact with African member states, taking the form of humanitarian aid, assistance in patrolling the coastal waters of these countries, and supplying sea training for their sailors (with most of these African navies having very few, if any, ocean-worthy warships).

The advent of the truly democratic South Africa in 1994 opened new doors (ports) for South African warships, and many flag-showing visits have since taken place, while many foreign warships have also visited South Africa, sometimes participating in exercises with the SAN. Whereas in the years up to the mid-1970s most foreign grey diplomats were RN ships, there have been many more visits by ships from other countries since 1994. This should not be seen as a deliberate moving away from the RN and other predominantly white Commonwealth navies by South Africa, but rather as an indication of how the country's interests have diversified, with more emphasis now being placed on contact with Third World countries (including Commonwealth countries that previously shunned South Africa) and powerful non-European/non-US countries such as Brazil, India and the People's Republic of China. The changing nature of global connections obviously also needs to be taken into account in this regard. Since 1994, the RN has remained a frequent visitor to South African ports, but relatively large formal exercises now take place on a regular basis with ships from Brazil, Argentina and Uruguay (ATLASUR), as well as Brazil and India (IBSAMAR). Of course, the SAN still has 


\section{3}

interaction with the RN, for example through its interaction with the North Atlantic Treaty Organisation.

Another factor that has to be taken into account in evaluating the history of the SAN, and its cooperation with Commonwealth (and other) navies in the course of the $20^{\text {th }}$ century and beyond, is the shifting demands confronting navies. The SAN and its predecessors developed from a small coastal force (1922-1933), a navy participating on a limited scale in a world war (1939-1945), a (small) bluewater navy (1945-1985) and a navy that placed the emphasis on defending its littoral waters (1985-2006) to a navy that is once again a small-scale but modern blue-water force. Whereas until 1967 all the major SAN ships were designed and built in the UK (thus endowing the SAN with the character of a "mini-RN"), most of the major SAN units of today are of German origin.

In the course of the past century, the SAN and its predecessors have served the Union and later the RSA with pride. They have protected local ports and shipping, and for many years supported the $\mathrm{RN}$ in its determination to retain command of the sea. In comparison with other Commonwealth navies, ${ }^{74}$ it is clear that today (2010), the SAN, with its three submarines and four frigates, is much stronger than the navies of, for example, Ghana, Nigeria, Tanzania, Kenya and the many small island countries, stronger than the New Zealand navy (two frigates), comparable to the navies of Malaysia (two submarines and four frigates) and Singapore (four submarines plus two more in the pipeline, and six frigates), but weaker than the navies of Canada (four submarines, three destroyers and twelve frigates), Australia (six submarines and twelve frigates), Pakistan (five submarines and seven frigates, plus three building), and India (seventeen submarines, one aircraft carrier [plus one fitting out], eight destroyers and fourteen frigates, with one submarine, three destroyers and four frigates building), while of all the Commonwealth navies, the $\mathrm{RN}$ is still the strongest (thirteen submarines and four building, three aircraft carriers, seven destroyers and five building, and seventeen frigates), albeit that the RN has been considerably scaled down ever since the end of the Cold War. ${ }^{75}$

Ever-increasing demands are being made on the SANDF to participate in UN or African Union peacekeeping operations. For this reason, it is also probable that the SAN will be more geared towards humanitarian and peace-support operations in future. Consequently, the need for at least one amphibious assault ship (preferably two) has been identified, while the remaining gun-boats and mine hunters will probably be replaced in due course by six multi-mission offshore patrol vessels. Comparable developments in other countries include the Australian Navy's decision to acquire two large amphibious assault ships and three air warfare 


\section{4}

destroyers, Canada's intention to acquire three multi-role joint support ships, and the New Zealand Navy's acquisition of a large multi-role ship, two offshore patrol vessels and four inshore patrol vessels.

The modern "new-look" SAN of the future will undoubtedly be able to play a meaningful role with regard to humanitarian and peacekeeping operations, and to contribute towards the combating of piracy (as it is currently already able to do, albeit on a more limited scale). It will also be able to contribute towards the envisaged African rapid-reaction force ${ }^{76}$ Financial constraints and the lack of a maritime culture among the largest portion of the population comprise challenges that are being faced by the SAN - both in terms of the present and also the foreseeable future. One can only hope that the political context will be conducive to the development and maintenance of a small but modern and well-trained naval force, on the one hand, and that within this context, the SAN will be utilised in a professional and circumspect manner, on the other hand. After all, the Navy is a very important instrument in foreign affairs, especially on a diplomatic level. South Africa cannot afford to be isolated, as was the case from the early 1960s until the late 1980s. Hopefully, in the course of the next decades of the $21^{\text {st }}$ century, the SAN will build on the naval ties that it has established since 1994, without neglecting its very important cooperation with Commonwealth navies- cooperation that dates back for a century.

\section{End notes}

1 Du Toit, A. 1992. South Africa's fighting ships: Past and present. Rivonia: Ashanti: xviii, xx.

2 .1912. Statutes of the Union of South Africa 1912. Cape Town: .Government printer.

3 Rice, B. 2001. The Royal Navy in South Africa 1900-2000. Liskeard: Maritime Books 3, 29, 30; The Natal Advertiser. 1913. 1 September: 3; The Natal Advertiser. 1913. 6 September: 3. The RN's battle-cruiser HMS New Zealand visited Simon's Town (March) and Durban in 1913. Pearson, T. 1995. "African keyport": Story of the port of Durban. Rossburgh: Accucut Books: 187.

4 Du Toit op. cit., pp. xxii-xxvii; Hay, S. 1920. History of the RNVR South African Division. Cape Town: Juta \& Co.: 193.

5 Du Toit op. cit., pp. 3-16.

6 Stevens, D. (ed.). 2001. The Royal Australian Navy. Melbourne: Oxford University Press: 11-22, 300-301.

7 Howard, C. 1982. The navy in New Zealand: An illustrated history. London: Jane's: 35; McDougall, F.J. 1989. New Zealand naval vessels. S.1.: GP Books: 2, 11, 16. 
8 Goosen, J.C. 1973. South Africa's navy: The first fifty years. Cape Town: W.J. Flesch: 37; Bennett, C.H. \& Söderlund, A.G. 2008. South Africa's navy: A navy of the people and for the people. Simon's Town: S.A. Navy: 19; Bryer, K. \& Stockton, B. (eds).1997. A navy for three oceans: Celebrating 75 years of the South African Navy. Simon's Town: S.A. Navy: 2.

9 Stevens op. cit., pp. 302-303; information supplied by Dr David Stevens, 23 February 2009.

10 McDougall op. cit., 5, 25-26, 62-63.

11 For a review of the naval activities off the South African coast, see Turner, L.C.F. Gordon, H.R. \& Betzler, J.E.1961. War in the southern oceans. Cape Town: O.U.P.

12 Wessels, A. 1994. Die opbou van die Unie-Verdedigingsmagte in die tydperk September 1939 tot September 1941. Journal for Contemporary History 19(3):1-22; Wessels, A. 1995. Die aanwending van die UnieVerdedigingsmagte in die tydperk September 1939 tot September 1941. Journal for Contemporary History 20(1):1-23; Du Toit op. cit., pp. 27-31.

13 Lever, M.P.H. . 1986. Sailor-women, sea-women, SWANS: A history of the South African Women's Auxiliary Naval Service 1943-1949. Simon's Town: Swans History Publication Fund..

14 Nöthling, C.J. 1995. Geskiedenis van die Suid-Afrikaanse Weermag 1. Silverton: SAMHIK: 58.

15 For a review of South Africa's role in the war against Japan, see Wessels, A. 2005. Die stryd teen Nippon: Suid-Afrika en Japan, 1941-1945. Journal for Contemporary History 30(3):222-241.

16 Bisset, W.M. 1982. SA naval personnel seconded to the Royal Navy during the Second World War 1939-1945. Simon's Town Historical Society Bulletin 12(2):55, 59; The South African naval forces 1939-1945. 1990. Brochure; André Wessels Private Document Collection (Bloemfontein), SA Vloot [file]: W.M. Bisset - A. Wessels, 6 May 1992 [letter]. See also the Naval Digest. 2001. 5:1-27 and ibid. 2008. 13:23-59. For a review of the role of South Africans in all naval sectors, see Harris, C.J. 1991. War at sea: South African maritime operations during World War II. Rivonia: Ashanti Publishing: passim.

17 Du Toit op. cit., p. 171.

18 Ibid.

19 Coetzer, P.W. (ed.). 1994. Die Nasionale Party 5: Van oorlog tot oorwinning. Bloemfontein: Academica; Posthuma, A.J. 1990. Generaal J.C. Smuts en Afrikaner-opposisie 1939-1948. Unpublished DLitt dissertation, University of South Africa, Pretoria.

20 Commando. 1951. 2(12): 4-7, 39 and ibid. 1951. 2(15): 4-7; Navy News. 1992. 11 April: 25; Du Toit op. cit., p. 161. For more information on the role of South Africa's grey diplomats, see Wessels, A. 1997. South Africa's grey diplomats: Visits by South African warships to foreign countries 1946-1996. Scientia Militaria 27:67-105; Wessels, A. 2002. Onwaarskynlike 
ambassadeurs: Vlagvertoonvaarte deur Suid-Afrikaanse oorlogskepe, 19222002. Journal for Contemporary History 27(3): 54-81.

21 Du Toit op. cit., p. 172.

22 Goosen op. cit., pp. 133-146; Henshaw, P.J. 1992. The transfer of Simonstown: Afrikaner nationalism, South African strategic dependence, and British global power. The Journal of Imperial and Commonwealth History 20(3):420-444; Die Burger. 1957, 2 February:1, 8, 9; The Cape Argus. 1957, 3 April:11.

23 Bennett \& Söderlund op. cit., pp. 43, 45.

24 See, for example, Commando.1957. 8(7):4, ibid. 1957. 8(12):37 and ibid. 1959. 10(11):6-7; The Admiralty News Summary. 1955. 105, May: 15; The Cape Argus. 1959. 20 June: 3 and ibid. 1959.24 September: 1; Bennett, C. 2006. Three frigates. Durban: Just Done Productions: 106-115. For a review of visits by warships to South African ports until 1961, see Wessels, A. 2006. Buitelandse vlagvertoonbesoeke aan Suid-Afrikaanse hawens (1): Vanaf die VOC-tydperk tot 1961. Journal for Contemporary History 31(1):81-98.

25 Du Toit op. cit., pp. 201-219; SA Naval Museum. N.d. History of the mine countermeasures flotilla 1922-1988.Unpublished manuscript: 23, 25-26; SANDF Documentation Service. 1958. Log-books of SAS Vrystaat, Johannesburg, Kimberley and Walvisbaai. Pretoria; Commando. 1958. 9(8):22-23.

26 Stevens op. cit., pp. 155-190; Goldrick, J. 1997. No easy answers: The development of the navies of India, Pakistan, Bangladesh and Sri Lanka, 1945-1996. New Delhi: Lancer Publishers: 1-32, 45-56; Blackman, R.V.B. (ed.). 1960. Jane's fighting ships 1960-61. London: Low, Marston: 59-90.

27 Beinart, W. 1994. Twentieth-century South Africa. Oxford: Oxford University Press: $156-162$.

28 Geyser, O. 1983. Watershed for South Africa: London 1961. Durban: Butterworths: 76-100; Scholtz, G.D. 1974. Dr Hendrik Frensch Verwoerd 2. Johannesburg: Perskor: 91-119.

29 For a review of visits made by warships to South African ports, 1961-1966, see Wessels, A. 2006. Buitelandse vlagvertoonbesoeke aan Suid-Afrikaanse hawens (2): Die periode van fluktuerende internasionale betrekkinge, 196194. Journal for Contemporary History 31(2): 78-82.

30 Williams, J.P. 1988. The arms embargo against South Africa: Success or futility? Journal for Contemporary History 13(1): 1; Bennett op. cit., pp. 37-38, 114115.

31 For the purpose of this article, the finer details of the Namibian War of Independence are not important. For more on the conflict see, for example, Steenkamp, W. 1989. South Africa's border war 1966-1989. Gibraltar: Ashanti, as well as the special editions of the Journal for Contemporary History 31(3), December 2006 and 34(1), February 2009, which deal with the war.

32 For more details with regard to the SAN's role in the war, see Wessels, A. 2006. The South African Navy during the years of conflict in Southern Africa, 
1966-1989. Journal for Contemporary History 31(3):283-303; Bennett op. cit., pp. 155-167.

33 André Wessels Private Document Collection (Bloemfontein), Grey diplomats [file]: W.D. Jones, List of ships visiting Simon's Town 1965-1978 (copy supplied by A. Söderlund) [henceforth referred to as the Jones manuscript], pp. 2-8.

34 For more on the role played by the Tafelberg in the SAN, see Wessels, A. 2007. Veertig jaar se ondersteuning ter see. Gevegsteunskepe in die SuidAfrikaanse Vloot, 1967-2007 (1): SAS Tafelberg en SAS Drakensberg. Journal for Contemporary History 32(2):164-182.

35 Du Toit op. cit., pp. 187, 226; SANDF Documentation Service. 1967. Log-books of SAS President Kruger and Tafelberg. Pretoria; information supplied by Cdr D.K. Kinkead-Weekes.

36 SA Navy News. 1968. 2(11): 17; Navy News. 1992. 11, June: 6; Simon's Town (town) Museum, press clipping book. She was Pakistan's first submarine. During the Indo-Pakistani War of 1971, she was sunk with all on board (4 December 1971). Blackman, R.V.B. (ed.). 1966. Jane's fighting ships 196667. London: Low, Marston: 202; Blackman, R.V.B. (ed.). 1972. Jane's fighting ships 1972-73. London: Low, Marston: 247.

37 Information supplied by Rear-Adm. (J.G.) Arné Söderlund, Mr Vic Jeffery and Mr Peter Reid. For more on Australia's "Oberon"-class submarines, see Sharpe, R. (ed.). 1990. Jane's fighting ships 1990-91. Coulsdon: Jane's Publishing Company:: 29. The other five new Australian submarines sailed to Australia via the Suez Canal (one) or the Panama Canal (four).

38 SA Naval Museum. 1968. Report of proceedings: Visit to Australia - period $7^{\text {th }}$ October to $3^{\text {rd }}$ December; Commando. 1969. 20(4): 13, 15 and ibid. 1969. 20(5): 13, 15, 25; Goosen op. cit., pp. 197-198; Du Toit op. cit. p. 226; Navy News. 1986. 8, December: 9.

39 Blackman op. cit. 1966-67, 12, 35, 202; Blackman, R.V.B. (ed.). 1968. Jane's fighting ships 1968-69. London: Sampson, Low, Marston: 130; Blackman op. cit., 1972-73 p. 154; Sharpe op. cit., p.: 23; Stevens op. cit., pp. 298-309.

40 Du Toit op. cit., pp. 267-272. For more on the history of the "Daphné"-class submarines in SAN service, see SA Naval Museum. History of the South African Navy submarine service. Typed manuscript, and Abbreviated history of SAN Submarine Branch. Typed manuscript; Ploeger, J., Bisset, W.M., Moolman, J.A., Spies, F.J. du T., Hyde, M.A., Knott, C.A., Buresh, J. \& Groome, A.K. 1999. Through the periscope. South African submarines: The first thirty years. Reflections past and present. Simon's Town: S.A. Navy: passim; Wessels, A. Duikbote in die Suid-Afrikaanse Vloot: Die eerste fase, 1970-2003 (published in two parts), Journal for Contemporary History 30(2), September 2005, pp. 180-194 and 30(3), December 2005, pp. 92-108.

41 Jones manuscript, p. 10; Du Toit op. cit., pp. 176, 229-230; Simon's Town Museum, newspaper clipping book. 
42 Du Toit Spies, F.J. 1989. Operasie Savannah: Angola 1975-1976. Pretoria: S.A. Weermag: passim; Barnard, S.L. 1991.'n Historiese oorsig van die gewapende konflik aan die noordgrens van SWA/Namibië 1966-1989. Acta Academica 23(1):112-114.

43 Bennett op. cit., pp. 155-166; Du Toit Spies op. cit., pp. 141-142, 147, 168, 174-176; Du Toit op. cit., pp. 231-232; Steenkamp op. cit., pp. 51-52.

44 Du Toit op. cit., pp. 281-289; Potgieter, T.D. 2000. Another apartheid dilemma: Corvettes for the South African Navy. New Contree 47, September: 94-95.

45 Du Toit op. cit., pp. 303, 309.

46 Du Toit op. cit., pp. 232-234; The Cape Times. 1980.18 August: 8; Bennett \& Söderlund op. cit., p. 35.

47 Steenkamp op. cit., pp. 89-117; Barnard op. cit., p. 119.

48 Bennett op. cit., pp. 187-201; Du Toit op. cit., 234-236.

49 For more on the Voyager disaster, see, for example, Stevens op. cit., pp. 201202. Later, on 3 June 1969, the Melbourne collided with and sank a warship from another country (the destroyer USS Frank E. Adams). See ibid., p. 203.

50 Du Toit op. cit., pp. 142-144, 176, 178, 207-210, 218-219, 255, 278-279.

51 Ibid., pp. 316-322; Wessels, A., Veertig jaar se ondersteuning ter see (1) op. cit., pp. 174-182 and Wessels, A. 2008. Veertig jaar se ondersteuning ter see. Gevegsteunskepe in die Suid-Afrikaanse Vloot, 1967-2007 (2): SAS Drakensberg en SAS Outeniqua. Journal for Contemporary History 33(1):144-145.

52 Steenkamp op. cit., pp. 117-184; Barnard op. cit., pp. 119-125; Stiff, P. 1991. Nine days of war. Second edition. Alberton: Lemur: passim.

53 For more details, see Blackman op. cit. 1966-67, pp. 11-17, 34-39, 125-129, 193-194, 202-204, 272-298; Sharpe op. cit., pp. 23-26, 77-82, 262-268, 407-409, 430-433, 675-690.

54 The Cape Times. 1994. 20 July: 6; The Star. 1994.19 July: 9; The Citizen. 1994. 21 July: 1.

55 For details, see Line-book: SAS Protea (consulted onboard the ship, July 1997); Navy News. 1990. 9, July: 12, 15, 17; ibid. 1990. August: 2, 10, 11, 15-16, 20; ibid. 1991. January/February: 12-13; ibid. 1991. 10, April/May: 12-16; Wardley, G. 1991. Operation Gypsy - SAS Tafelberg's South American adventure. Unisa Latin American Report 7(2): 89; The Natal Mercury. 1990, 5 June: 6; Du Toit op. cit., pp. 307, 320.

56 The Natal Mercury. 1992. 19 June: 1 and ibid. 1992, 25 June: 12.

57 Navy News. 1992. 11, November/December: 2 and ibid. 1992. 12, January/February: 10-11; Paratus. 1992. 43(11):18-19; Sunday Tribune. 1992. 11 October: 8-9.

58 For the role of the Outeniqua in the SAN, see Wessels op. cit. pp. 144-145.

59 Line-book: SAS Protea; Die Volksblad. 1993, 19 March: 9; Navy News. 1993.12, May: 16.

60 Navy News. 1993. 12, August: 8-11, 14-15; The Natal Mercury. 1993. 25 May: 5; Paratus. 1993. 44(6):15. 
61 Navy News. 1994. 13, March: 11-13; Die Burger. 1994. 5 January: 1 and ibid. 1994. 27 January: 17; The Star. 1994. 5 January: 1 and ibid. 1994. 28 January: 5.

62 Navy News. 1994.13, June: 18 and ibid. 1994. 14, October: 12-16; Salut. 1994. 1(2):50-51 and ibid. 1994. 1(6): 26-28; Ad Astra. 1994. 15(10): 18-19.

63 For details, see SA Naval Museum: Report of proceedings - Operation Maroela 2 to 29 September 1994; Navy News. 1994. 13, November/December: 12-13; ibid. 1994. 14, October: 2 and ibid. 1994. 14, November/December: 9; Sunday Times. 1994, 16 October: 4; ibid. 1995. 14 May:12-14;and1996. 3(11):58-59.

64 For details, see Wessels, A. 2007. Buitelandse vlagvertoonbesoeke aan SuidAfrikaanse hawens (3): Die eerste dekade van die nuwe RSA, 1994-2004. Journal for Contemporary History 32(1):223-227; Navy News. 1997. 16(3):4-7, 10-23.

65 For details, see Navy News. 1997. 16(5): 7; ibid. 1997. 16(6): 32; ibid. 1998. 17(1): 12-17; ibid. 1999. 18(4): 10-15; ibid. 1999. 18(7): 15; ibid. 2000. 19(6): 29-31; ibid. 2001. 20(2): 22; ibid. 2001. 20(4): 16 and ibid. 2001. 20(5): 14; Salut. 1998. 5(1): 32-34; ibid. 1999. 6(1): 33; ibid. 2000. 7(9): 63 and ibid. 2000. 7(12): 37; Defense Affairs of Africa and the Middle East. 1998. 1(3): 13; The Mercury. 1999. 21 April: 7; ibid. 1999. 28 April: 9 and ibid. 1999. 12 May: 9; Daily News.1999. 14 April: 1; Wessels, A. Buitelandse vlagvertoonbesoeke . (3) op. cit., pp. 230-237.

66 Line-book: SAS Outeniqua (consulted at the SA Naval Museum); Navy News. 2001. 20(6): 14-16.

67 Bennett \& Söderlund op. cit., pp. 61, 63; SA Shipping News and Fishing Industry Review. 2001. 56(3): 12; SAN Info Bulletin. 2001. 46/01; SA Navy Info Bulletin. 2001. 16/01; South African Soldier. 2001. 8(2): 20; Navy News. 2001.20(2): 2-4.

68 South African Soldier. 2005. 12(11):22; Navy News. 2003. 22(6): 11.

69 Navy News. 2003. 22(6): 16-18, 20, 22-23; ibid. 2004. 23(2): 17-19, 22-27; ibid. 2004. 23(3): 15-22; ibid. 2004. 23(5): 21-28; ibid. 2006. 25(2): 22-23; ibid. 2007. 26(3): 18-23 and ibid. 2008. 28(3): 16-17; South African Soldier.2004. 11(5): 18-19; ibid.2004. 11(9): 5 and ibid. 2004. 1(11): 18-20.

70 Salut. 1999. 6(1): 14-19; The Mercury. 1998. 19 November: 1; Beeld. 1998. 19 November: $1-2$.

71 See, for example, Navy News. 2010. 29(1): 16-20.

72 See, for example, ibid. 2006. 25(4): 26-31; ibid. 2007. 26(3): 26-33; ibid. 2007. 27(6): 18-21 and ibid. 2008. 28(6): 20.

73 See, for example, ibid. 2005. 24(3): 16-17; ibid. 2005. 24(4): 7, 14; ibid. 2005. 24(5): 7, 24-31; ibid. 2006. 25(4): 15; ibid. 2007. 26(1): 5 and ibid. 2008. 27(3): 18-21; The Mercury. 2005. 22 July: 7.

74 See Saunders, S. (ed.). 2009. Jane's fighting ships 2009-2010. Coulsdon: Jane's Information Group: passim. 
75 In 1990, the RN still had 32 submarines, 3 aircraft carriers, 13 destroyers and 36 frigates. See Sharpe op. cit. pp. 675-690.

76 For more on the African rapid reaction force, see, for example, Wessels, A. 2008. A rapid reaction force for Africa, with special reference to southern Africa and the role that the South African National Defence Force can play. In T. Potgieter (ed.-in-chief). Regions, regional organisations and military power. Proceedings of the XXXII ${ }^{\text {nd }}$ International Congress of Military History, Cape Town, 2007. Stellenbosch: 603-613. 